\title{
Dra. MARIA da GRAÇA FERREIRA (1966-1997) IN MEMORIAM
}

No dia 10 de Maio de 1997, faleceu, em Coimbra, após doença galopante e implacável, a Dra. Maria da Graça Ferreira, Assistente do Instituto Universitário de Desenvolvimento e Promoção Social.

Neste volume de Gestão e Desenvolvimento que se publica após tão doloroso acontecimento, constitui dever indeclinável de quem teve, primeiro, a Dra. Maria da Graça Ferreira como Aluna, depois, como Colega e Amiga, deixar expressa uma singela evocação da sua memória.

Não desconhecendo a dificuldade da tarefa, tanto mais que se está perante uma personalidade excepcional, que se recorta a traços vivos da penumbra de tantas existências sem sentido nem ideal, procuremos destacar os traços essenciais desta jovem Assistente do Pólo de Viseu da Universidade Católica Portuguesa, prematuramente subtraída ao nosso convívio.

Natural da freguesia e concelho de Vil de Souto, Maria da Graça Ferreira, completados os estudos secundários e obtida a aprovação no Ano Propedêutico, inscreveu-se no $1 .^{\circ}$ ano da licenciatura em Gestão e Desenvolvimento Social, tendo pertencido ao primeiro curso desta licenciatura - 1986-1991 - ministrada pelo Instituto Universitário de Desenvolvimento e Promoção Social, após a respectiva criação pelo Conselho Superior da Universidade Católica Portuguesa em 1986.

Ao longo dos cinco anos da licenciatura, revelou qualidades intelectuais e de carácter, que cedo a impuseram à admiração de professores e colegas, e que confirmaria a sua carreira académica. Não só era patente a sua inteligência e capacidade de estudo, mas também se lhe reconhecia uma personalidade forte e assertiva, assumindo por inteiro as suas convicções.

Após uma carreira escolar brilhante, concluiu, em 1991, a licenciatura com informação final de Bom, tendo obtido 19 valores no Estágio e 18 no Seminário de Psicologia.

Porque a tivemos como aluna nesta unidade curricular, pudemos verificar muito concretamente o nível que atingiu o trabalho de Seminário que elaborou, 
intitulado As expectativas dos jovens face ao futuro (Viseu, 1991), tema, entre os que propusemos no ano lectivo de 1990/91, que mereceu a sua escolha.

Com uma extensão pouco frequente $(252$ p.) em trabalhos do género. As expectativas dos jovens face ao futuro evidenciava já qualidades de investigação que o prosseguimento da sua, ainda que breve, carreira académica confirmaria plenamente. Com efeito, não só apreendeu o sentido da temática da perspectiva temporal do futuro, como foi perfeitamente adequado o enfocamento teórico a que procedeu na parte inicial do capítulo $I$.

Mas não foram apenas aqueles pontos que valorizaram o trabalho de Seminário de Maria da Graça Ferreira. O rigor conceptual e terminológico que revela, a clareza e sistematização na exposição, o tratamento de dados preciso e fundamentado constituem outros aspectos merecedores de destaque. Registe-se que, entre as conclusões do trabalho de Seminário que apresentou, foi confirmada a hipótese segundo a qual as expectativas face ao futuro foram diferentes entre os jovens do sexo masculino e do sexo feminino que constituíram a amostra da investigação empírica que efectuou.

Por outro lado, Maria da Graça Ferreira concluiu «que a família desempenha um papel importante reconhecido pelos jovens. Esta é por eles considerada como indispensável para a segurança afectiva e para a formação da personalidade.» ( $p$. 204).

A brilhante carreira académica de Maria da Graça Ferreira justificava plenamente a sua contratação como Assistente Estagiária do I.U.D.P.S., funções que iniciou no ano lectivo de 1991/92.

No decurso da sua carreira universitária, assegurou o serviço docente de disciplinas como Métodos e Técnicas de Investigação, Sociologia do Trabalho e Gestão de Recursos Humanos.

Foi, também, supervisora do Estágio curricular da licenciatura em Gestão e Desenvolvimento Social. Relativamente a este - e porque tivemos a nosso cargo, durante vários anos, a coordenação do funcionamento do mesmo -, cumpre-nos salientar a extraordinária actividade que desempenhou nas diversificadas tarefas que o mesmo comporta - contacto e selecção dos centros de Estágio, acompanhamento e supervisão das actividades dos Estagiários e apreciação dos Relatórios de Estágio. Nos volumes 2, 3 e 4 de Gestão e Desenvolvimento apresentou, na secção Vida e actividades do I.U.D.P.S., um relato documentado dos Centros de Estágio que têm funcionado desde o ano lectivo de 1990/91.

A carreira universitária da Dra. Maria da Graça Ferreira foi marcada, não só por inegável competência científica, mas também por evidentes qualidades pedagógicas, bem como pelo apoio prestado aos seus alunos e a todos os que lho solicitavam.

Para lhe permitir a passagem da categoria de Assistente Estagiária à de Assistente, a Dra. Maria da Graça Ferreira frequentou, no Instituto Superior de Ciências do Trabalho e da Empresa, o Curso de Mestrado em Políticas e Gestão de Recursos Humanos. Viria a concluir este curso com a defesa da dissertação inti- 
tulada Modernização empresarial e a renovação dos perfis profissionais. $O$ sector têxtil no Vale do Ave.

Orientada pela Prof. ${ }^{a}$ Maria João Rodrigues, a dissertação de mestrado de Maria da Graça Ferreira teve como objectivos «identificar e caracterizar os perfis profissionais exigidos para os trabalhadores das empresas do sector têxtil...»e «analisar em que medida o processo de modernização por que está a passar [o mesmo] se está a reflectir na recomposição dos perfis profissionais.» (p. 11).

No desenvolvimento da sua dissertação, aborda, numa primeira parte, o quadro teórico de que partiu e, numa segunda, apresenta a metodologia do trabalho empírico que efectuou em seis empresas do sector têxtil.

Considerando, na parte teórica, que «os perfis profissionais existentes num sector dependem fundamentalmente da configuração tecnológica e da trajectória tecnológica que o caracteriza, dos modelos organizacionais predominantes e das competências disponíveis para esse sector», analisa, na parte empírica, a metodologia seguida, bem como os resultados da investigação que efectuou, apoiada num estudo de caso e em diversos instrumentos, entre os quais em questionários.

Marcada por uma preocupação de fundamentação teórica e por uma adequada metodologia, a dissertação de mestrado de Maria da Graça Ferreira caracterizou-se pelo rigor de análise, pelo sentido crítico e pela capacidade interpretativa, além de focar uma temática dotada da maior actualidade, atendendo ao papel da modernização tecnológica e aos seus efeitos sobre a renovação dos perfis profissionais, no caso vertente, no sector têxtil.

Para além dos aspectos já referidos da carreira universitária de Maria da Graça Ferreira, impõe-se, também, salientar o investimento que colocava em todas as tarefas que exercia, a capacidade organizativa que revelava e o espírito de colaboração que lhe era tão peculiar.

A terminar este In memoriam de Maria da Graça Ferreira - que deixa, em todos os que a admirávamos e éramos seus amigos, uma saudade imperecível procuremos ser dignos do seu exemplo, pois, ainda que tendo uma vida breve, a preencheu com a marca de uma personalidade de excepção.

Nicolau Vasconcelos Raposo 